\title{
OCCURRENCE OF AFLATOXIN M IN PARMESAN CHEESE CONSUMED IN MINAS GERAIS, BRAZIL
}

\author{
Ocorrência de aflatoxina $M_{1}$ em queijo Parmesão consumido em Minas Gerais, Brasil
}

\author{
Guilherme Prado1, Marize Silva de Oliveira², Adriana Souza Lima², Ana Paula Aprigio Moreira ${ }^{3}$
}

\begin{abstract}
RESUMO
Aflatoxina $\mathrm{M}_{1}\left(\mathrm{AFM}_{1}\right)$ pode ocorrer em leite e produtos de leite, resultante da ingestão de aflatoxina $\mathrm{B}_{1}$ presente em rações de gado leiteiro. Um total de 88 amostras de queijo Parmesão, comercializadas no estado de Minas Gerais, Brasil, no período de março de 2004 a dezembro de 2004, foram analisadas para aflatoxina $M_{1}$ por cromatografia líquida de alta eficiência (CLAE) com detector de fluorescência, precedida de purificação da amostra por coluna de imunoafinidade. AFM foi detectada em 40 das 88 amostras $(46,4 \%)$. Entretanto, somente duas amostras entre estas estavam contaminadas em um nível acima do limite máximo permitido (250 $\mathrm{ng} \mathrm{kg}^{-1}$ ), aceito pela Comunidade Européia para $\mathrm{AFM}_{1}$. O Brasil não apresenta tolerância máxima permitida para $\mathrm{AFM}_{1}$ em queijo.
\end{abstract}

Termos para indexação: Aflatoxina $M_{1}$, queijo, ocorrência.

\begin{abstract}
Aflatoxin $\mathrm{M}_{1}\left(\mathrm{AFM}_{1}\right)$ may occur in milk and milk products, resulting from the ingestion of aflatoxin $\mathrm{B}_{1}$ in feedstuffs by dairy cow. A total of 88 samples of Parmesan cheese marketed in Minas Gerais state, Brazil, from March 2004 to December 2004, were analyzed for AFM 1 by high-performance liquid chromatography (HPLC) with a fluorescence detector following sample clean-up using immunoaffinity columns. AFM 1 was detected in 40 of the 88 samples (46.4\%). However, only two samples among these were contaminated at a level above the maximum permissible limit $\left(250 \mathrm{ng} \mathrm{kg}^{-1}\right)$ accepted by European Union for AFM No $_{1}$ AFM $_{1}$ maximum tolerance limit in cheese has been established in Brazil.
\end{abstract}

Index terms: Aflatoxin $\mathrm{M}_{1}$, cheese, occurrence.

(Received in september 28, 2006 and approved in may 16, 2007)

\section{INTRODUCTION}

Aflatoxins are a group of mycotoxins mainly produced by common fungi Aspergillus flavus, A.parasiticus and A.nomius. These fungi are ubiquitous and can occur in a wide range of agricultural commodities, such as cereals, nuts, dried fruit and in feedstuffs. A. flavus only produces $\mathrm{B}$ aflatoxins, while the other two species produce both $B$ and $G$ aflatoxins. Aflatoxins $M_{1}\left(A_{1} M_{1}\right)$ and $\mathrm{M}_{2}\left(\mathrm{AFM}_{2}\right)$, are the hydroxylated metabolites of aflatoxin $\mathrm{B}_{1}\left(\mathrm{AFB}_{1}\right)$ and $\mathrm{B}_{2}\left(\mathrm{AFB}_{2}\right)$, respectively, and may be found in milk and milk products from livestock that have ingested contaminated feed (CALONI et al., 2006; CREPPY, 2002).

Many researchers reported that there was a linear relationship between the amount of $\mathrm{AFM}_{1}$ in milk and $\mathrm{AFB}_{1}$ in feed consumed by the animals. It is estimated that approximately $1-6 \%$ of the $\mathrm{AFB}_{1}$ initially present in the animal feedstuff appears as $\mathrm{AFM}_{1}$ in milk. $\mathrm{AFM}_{1}$ could be detected in milk 12-24 $\mathrm{h}$ after the first aflatoxin $\mathrm{B}_{1}$ ingestion, reaching a high level after a few days, probably associated with the protein fraction (BAKIRCI, 2001; BATTACONE et al., 2003; DRAGACCI et al., 1995; PITTET, 1998).

$\mathrm{AFM}_{1}$ is less mutagenic and carcinogenic than $\mathrm{AFB}_{1}$ but it exhibits high genotoxic activity (BARNES, 1970; CANTON et al., 1975; JECFA, 2001; LAFONT et al., 1989; SINNHUBER et al., 1974). $\mathrm{AFB}_{1}$ and $\mathrm{AFM}_{1}$ are classified as a potential carcinogenic agent in the group 1 and 2B, respectively to humans (IARC, 1993).

Milk and milk products are a good source of many nutrients such as proteins and calcium and are mainly consumed by children. Therefore, humans are potentially exposed to these toxic metabolites and it is generally assumed that neither storage nor processing determines a reduction of $\mathrm{AFM}_{1}$ content (DIAZ \& ESPITIA, 2006; GALVANO et al., 1996; GARRIDO et al., 2003). In order to reduce this risk, many countries have regulated the levels

\footnotetext{
'Doutor - Laboratório de Micologia e Micotoxinas - Fundação Ezequiel Dias/FUNED - Rua Conde Pereira Carneiro, 80, Gameleira - 30510-010 Belo Horizonte, MG - gui@funed.mg.gov.br

'Mestres - Laboratório de Micologia e Micotoxinas - Fundação Ezequiel Dias/FUNED - Rua Conde Pereira Carneiro, 80, Gameleira - 30510-010 Belo Horizonte, MG - mar@funed.mg.gov.br; dricasoli@funed.mg.gov.br

${ }^{3}$ Graduada - Laboratório de Micologia e Micotoxinas - Fundação Ezequiel Dias/FUNED - Rua Conde Pereira Carneiro, 80, Gameleira - 30510-010 Belo Horizonte, MG - anap.aprigio@gmail.com
} 
of $\mathrm{AFB}_{1}$ in feeds and have set or proposed maximum permissible levels of $\mathrm{AFM}_{1}$ in milk and dairy products. By the end of 2003, data regarding to $\mathrm{AFM}_{1}$ regulations in dairy products existed in 60 countries. The legal limits of $\mathrm{AFM}_{1}$ are highly variable: many European countries have set a limit of $0.05 \mu \mathrm{g} \mathrm{kg}^{-1}$ AFM1 for dairy products while the USA and several Asian and European countries applied a limit ten fold higher (FAO, 2003; ORUC et al., 2006). Brazil has established a limit of $0.5 \mu \mathrm{g} \mathrm{kg}^{-1}$ for milk. However, no $\mathrm{AFM}_{1}$ levels have been officially set for milk products (BRASIL, 2002).

A number of survey and monitoring programs have been carried out in several countries to obtain general pattern of extent of milk, cheese and yoghurt contamination (AYCICEK et al., 2005; BARRIOS et al., 1996; CARVAJAL et al., 2003; DRAGACCI \& FREMY, 1996; ELGERBI et al., 2004; GALVANO et al., 2001; GÜRBAY et al., 2006; KAMBAR, 2005, 2006; KIM et al., 2000; LÓPEZ et al., 2001; MARTINS \& MARTINS, 2004; NAKAJIMA et al., 2004; ORUC et al., 2006; ROUSSI et al., 2002; SRIVASTAVA et al., 2001; TEKINSEN \& TEKINSEN, 2005).

In Brazil there are limited surveys for $\mathrm{AFM}_{1}$ in milk (GARRIDO et al., 2003; OLIVEIRA et al., 1997, 2006; PARREIRAS \& GOMES, 1987; PEREIRA et al., 2005; PRADO et al., 1999; SABINO et al., 1989; SOUZA et al., 1999; SYLOS et al., 1996; TAVEIRA \& MÍDIO, 2001) and milk products as yoghurt and cheese (PRADO et al., 2000, 2001; SYLOS et al., 1996).

$\mathrm{AFM}_{1}$ is relatively stable during pasteurization, sterilization, preparation, and storage of various dairy products (GALVANO et al., 1996; GÜRBAY et al., 2006; HASSANIN, 1994). Contrasting data have been reported on the influence of cheese preparation on $\mathrm{AFM}_{1}$ recovery. The first studies, performed in the years of 1971-1974, showed variable losses of $\mathrm{AFM}_{1}$ during cheese manufacturing. In contrast, later investigations reported increases in $\mathrm{AFM}_{1}$ concentration in cheese as a function of cheese type, technologies, and the amount of water eliminated during processing (BASKAYA et al., 2006; KAMBAR, 2006).

The consumption of cheese is widespread in Brazil. For this purpose, this study was designed to determine the presence and levels of $\mathrm{AFM}_{1}$ in Brazilian Parmesan cheese consumed in Minas Gerais state, Brazil.

\section{MATERIALS AND METHOD}

\section{Samples}

A total de 88 samples of Parmesan cheese were obtained randomly from different groceries and supermarkets located in several cities of Minas Gerais state, Brazil, from March 2004 to December 2004. The samples were taken in 200-250 g quantities and analyzed within 1 month from collection.

\section{Aflatoxin $\mathrm{M}_{1}$ determination}

Analysis was carried out in duplicate as described by Dragacci et al. (1995) and Tuinstra et al. (1993) briefly outlined as below.

Ten $\mathrm{g}$ of samples of cheeses were put in a bowl with dichloromethane $(80 \mathrm{~mL})$ and $10 \mathrm{~g}$ of Hyflo-supercel and the whole was blended for $2 \mathrm{~min}$ at high speed. After washing with further dichloromethane $(40 \mathrm{~mL})$, the mixtures were filtered and the filtrate was then evaporated at $60{ }^{\circ} \mathrm{C}$ under nitrogen. The residue was dissolved in methanol (1 $\mathrm{mL})$, water $(30 \mathrm{~mL})$ and $\mathrm{n}$ - hexane $(50 \mathrm{~mL})$, transfered in a separatory funnel and the aqueous phase collected. The hexane phase was then washed twice with water $(10 \mathrm{~mL})$ and the water phases also collected.

The aqueous collections were passed through an immunoaffinity column obtained from VICAM (Aflatest, Vicam, Watertown, MA, USA), according to the instructions of the manufacturer. Subsequently, the column was washed with water and the toxin was then eluted by acetonitrile, evaporated to dryness under a gentle stream of nitrogen and reconstituted to $500 \mu \mathrm{l}$ with acetonitrile-water (30:70, $\mathrm{v} / \mathrm{v}$ ) before the injection of $50 \mu \mathrm{l}$ into the liquid chromatographic system. Each extract was injected in triplicate.

$\mathrm{AFM}_{1}$ was quantified by reversed-phase HPLC (LC10 AD, Shimadzu, Japan, linked to a Auto Sampler SIL 10AF and Shimadzu RF551 fluorescence detector: excitation 366 $\mathrm{nm}$, emission $428 \mathrm{~nm}$ ), using a Shim-Pack CLC-ODS column, $5 \mu \mathrm{m}, 250 \mathrm{~mm} \times 4.6 \mathrm{~mm}$ i. d., preceded by a guard column Shim-Pack G-ODS, $5 \mu \mathrm{m}, 10 \mathrm{~mm}$ x $4 \mathrm{~mm}$ i. d. The mobile phase was isocratic, acetonitrile-isopropyl alcoholwater $(8: 12: 80, \mathrm{v} / \mathrm{v} / \mathrm{v})$, filtered through a $0.45-\mu \mathrm{m}$ filter membrane, degassed and used at a flow rate of $1 \mathrm{ml} / \mathrm{min}$ (DRAGACCI et al., 2001). Under these conditions, the retention time of $\mathrm{AFM}_{1}$ was approximately 8.6-9.5 min. HPLC solvents were of HPLC grade (EM Science or J. T. Baker) and other chemicals were of analytical reagent grade. A calibration curve of $\mathrm{AFM}_{1}$ was obtained using standard from Sigma (Code A-6428; St. Louis, MO, USA), at concentrations of $0.5-8.0 \mathrm{ng} \mathrm{ml}^{-1}$. The concentrations were determined according to AOAC (1995). The correlation coefficient was higher than 0.999 . The limit of detection and quantification, was $10 \mathrm{ng} \mathrm{kg}^{-1}$ and $20 \mathrm{ng} \mathrm{kg}^{-1}$, respectively. 


\section{RESULTS AND DISCUSSION}

The incidence of $\mathrm{AFM}_{1}$ contamination in Parmesan cheese was not very high, since $46.4 \%$ (40/88) of all samples were positive. Only two samples $(2.3 \%)$ were contaminated with $\mathrm{AFM}_{1}$, with $270 \mathrm{ng} \mathrm{kg}^{-1}$ and $660 \mathrm{ng} \mathrm{kg}^{-1}$, over the permissible level of $250 \mathrm{ng} \mathrm{kg}^{-1}$ as accepted in most European countries. Fourteen samples (15.9\%) were contaminated with low levels ranging from 10 to $19 \mathrm{ng} \mathrm{kg}^{-1}$. Twenty four samples $(27.3 \%)$ were contaminated with levels ranging from 20 to $250 \mathrm{ng} \mathrm{kg}^{-1}$ and mean concentration of aflatoxin $\mathrm{M}_{1}$ of 54.8 $\mathrm{ng} \mathrm{kg}{ }^{-1}$. The results are shown in Table 1 .

Few surveys have been undertaken to assess the level of $\mathrm{AFM}_{1}$ in some types of cheese consumed in Brazil (Table 2).

Sylos et al. (1996) detected no AFM in cheese commercialized, in 1990, in Campinas/Brazil. However, the analytical method employed was a thin-layer chromatography which is less sensitive than high-performance liquid chromatography (HPLC).

Prado et al. (2000) detected in 56 (74.7\%) of 75 white cheese samples AFM contamination and 20 (26.7\%) of the positive samples were found higher than $250 \mathrm{ng} \mathrm{kg}^{-1}$.

Prado et al. (2001) examined $\mathrm{AFM}_{1}$ levels in yellow cheese samples and in all brands analysed $\mathrm{AFM}_{1}$ was detected in the range of $20-540 \mathrm{ng} \mathrm{kg}^{-1}$ and mean level of
$150 \mathrm{ng} \mathrm{kg}^{-1}$. They found that 2 samples out of 9 exceeded $250 \mathrm{ng} \mathrm{kg}^{-1}$

Some previous studies in different countries have reported that $\mathrm{AFM}_{1}$ was not found in cheese samples. On the other hand some have reported high levels or lowlevels of $\mathrm{AFM}_{1}$ in cheese samples (SARIMEHMETOGLU et al., 2004).

Pietri et al. (1997) checked 223 samples of Grana Padano cheese manufactured in 4 years (1991-1994) and it has emerged that only one sample exceeded the maximum tolerated level in cheese in some European countries (250 $\left.\mathrm{ng} \mathrm{kg}{ }^{-1}\right)$. Most samples (91\%) were found in the range of 5$100 \mathrm{ng} \mathrm{kg}^{-1}$ and only 15 (67\%) was found in the range of 100-250 $\mathrm{ng} \mathrm{kg}^{-1}$.

Oruc \& Sonal (2001) examined AFM levels in cheese from Bursa, Turkey and found in $89.5 \%$ of cheese samples with range of $0-810 \mathrm{ng} \mathrm{kg}^{-1}$.

Sarimehmetoglu et al. (2004) detected in 327 (81.75\%) of 400 cheese samples $\mathrm{AFM}_{1}$ contamination. The number of cheese samples which exceeded the limits of $250 \mathrm{ng} \mathrm{kg}^{-}$ ${ }^{1}$ was $110(27.5 \%)$.

Aycicek et al. (2005) examined AFM levels in dairy products and the contamination was $90.58 \%$ (202 samples of 223) whereas $\mathrm{AFM}_{1}$ was not detected in 21 samples $(9.42 \%)$

Table 1 - Incidence and levels of AFM 1 in Parmesan cheese samples determined by HPLC from Brazil.

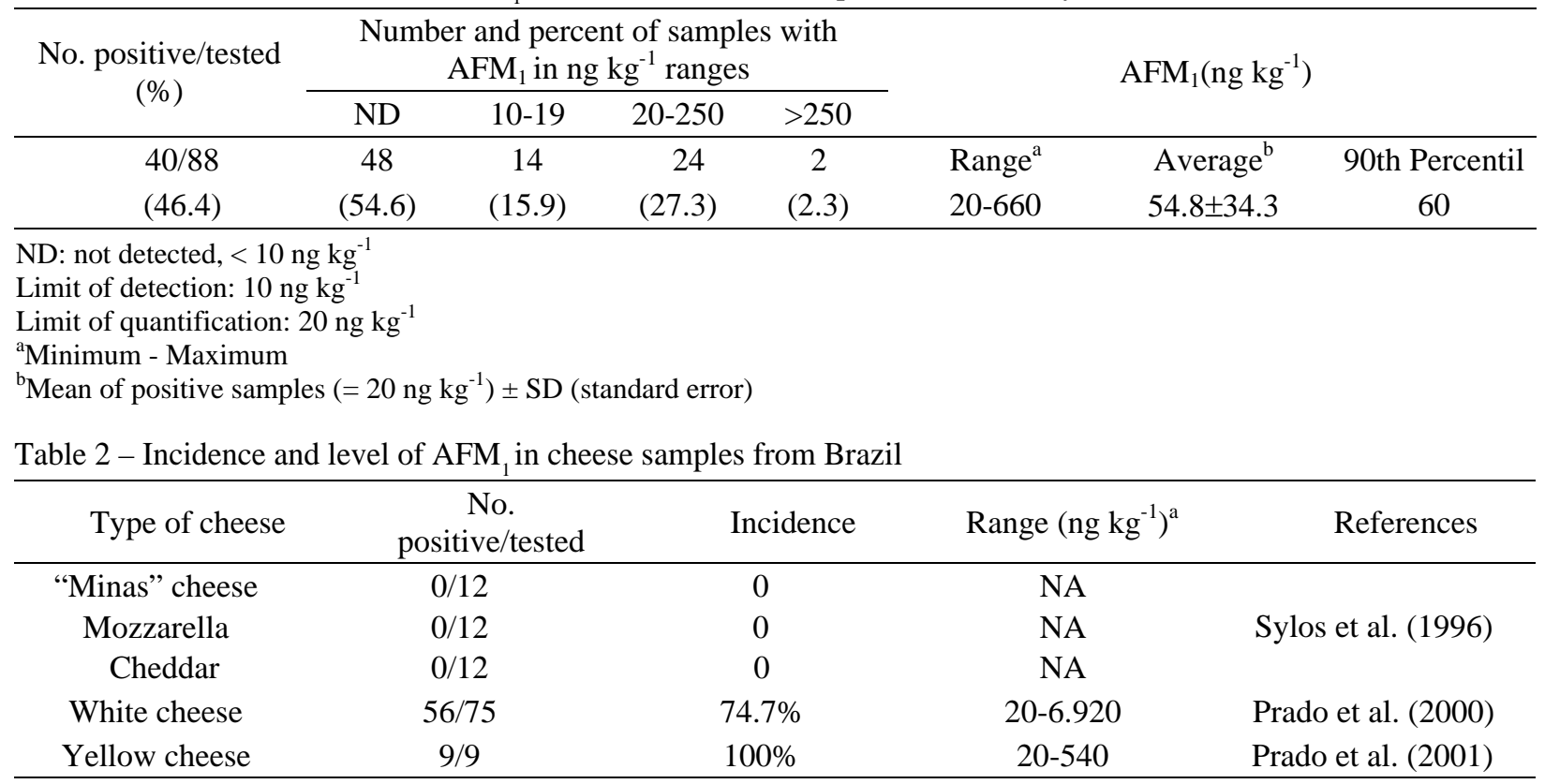

${ }^{a}$ Minimum-Maximum

NA- not applicable 
Kamber (2005) verified a total de 60 samples of Turkish cheese types, to determine the presence and the level of $\mathrm{AFM}_{1}$. The concentration of $\mathrm{AFM}_{1}$ was found to range from 51-115 $\mathrm{ng} \mathrm{kg}^{-1}$. The mean values of $\mathrm{AFM}_{1}$ were $82.5 \mathrm{ng} \mathrm{kg}^{-1}$ in Cecil cheese samples and $62.4 \mathrm{ng} \mathrm{kg}^{-1}$ in Kars Kashar cheese samples. None of the $\mathrm{AFM}_{1}$ levels were above the limit of $250 \mathrm{ng} \mathrm{kg}^{-1}$.

More recently, $\mathrm{AFM}_{1}$ levels were determined in 600 cheese samples from some provinces of Turkey. AFM was detected in $30(5 \%)$ cheese samples and in $6(1 \%)$ exceeded the Turkish legal limits of $250 \mathrm{ng} / \mathrm{kg}$ (YAROGLU et al., 2005). However, Baskaya et al. (2006) checked 363 cheese samples in Istanbul from 2002 to 2004, and AFM levels in 80 (22.04\%) were higher than $250 \mathrm{ng} \mathrm{kg}^{-1}$.

\section{CONCLUSION}

Although in some cases $\mathrm{AFM}_{1}$ concentrations in the cheese samples were found to be low, cheese is a very strong source of $\mathrm{AFM}_{1}$ among dairy products. For this reason, milk and dairy products have to be inspected continuously for AFM contamination. Finally, since there is not enough study in Brazil about the content of milk and dairy products, more studies are required to be done. Beside this, it is important to determine $\mathrm{AFM}_{1}$ levels in certain cheese samples consumed in Brazil. Monitoring the AFM in milk products in Brazil is the first step to support the establishment of legislation that could diminish risk to consumers and protect commercial activities.

\section{REFERENCES}

ASSOCIATION OF OFFICIAL ANALYTICAL CHEMISTRY. Official methods of analysis. 16. ed. Arlington, 1995.

AYCICEK, H.; ABDURRAHMAN, A.; SAYGI, S. Determination of aflatoxin levels in some dairy and food products which consumed in Ankara, Turkey. Food Control, Oxford, v. 16, p. 263-266, 2005.

BAKIRCI, I. A study on the occurrence of aflatoxin $M_{1}$ in milk and milk products produced in Van province of Turkey. Food Control, Oxford, v. 12, p. 47-51, 2001.

BARNES, J. M. Aflatoxin as health hazard. Journal of Applied Bacteriology, Oxford, v. 33, p. 285-298, 1970.

BARRIOS, M. J.; GUALDA, M. J.; CABANAS, J. M.; MEDINA, L. M.; JORDANO, R. Occurrence of aflatoxin $M_{1}$ in cheeses from south of Spain. Journal of Food Protection, Des Moines, v. 59, n. 8, p. 898-900, 1996.
BASKAYA, R.; AYDIN, A.; YILDIZ, A.; BOSTAN, K. Aflatoxin $\mathrm{M}_{1}$ levels of some cheese varieties in Turkey. Medycyna Veterynaryjna, [S.1.], v. 62, n. 7, p. 778-780, 2006.

BATTACONE, G.; NUDDA, A.; CANNAS, A.; CAPPIOBORLINO, A.; BOMBOI, G.; PULINA, G. Excretion of aflatoxin $M_{1}$ in milk of dairy ewes treated with different doses of aflatoxin $\mathrm{B}_{1}$. Journal of Dairy Science, Champaign, v. 86 , p. 2667-2675, 2003.

BRASIL. Agência Nacional de Vigilância Sanitária. Resolução $n^{\circ} .274$, de 15 de outubro de 2002. Aprova o regulamento técnico sobre limites máximos de aflatoxinas admissíveis no leite, no amendoim e no milho. Diário Oficial [da] República Federativa do Brasil, Brasília, 16 out. 2002.

CALONI, F.; STAMMATI, A.; FRIGGÈ, G.; ANGELIS, I. de. Aflatoxin $\mathrm{M}_{1}$ absorption and cytotoxicity on human intestinal in vitro model. Toxicon, Elmsford, v. 47, p. 409-415, 2006.

CANTON, J. H.; KROES, R.; LOGTEN, M. J. van; SCHOTHRST, M. van; STAVENUITER, J. F. C.; VERHULSDONK, C. A. H. The carcinogenicity of aflatoxin $\mathrm{M}_{1}$ in rainbow trout. Food and Cosmetics Toxicology, Oxford, v. 13, p. 441-443, 1975.

CARVAJAL, M.; BOLANÖS, A.; ROJO, F.; MÉNDEZ, I. Aflatoxin $M_{1}$ in pasteurized and ultrapasteurized milk with different fat content in Mexico. Journal of Food Protection, Des Moines, v. 66, n. 10, p. 1885-1892, 2003.

CREPPY, E. E. Update of survey, regulation and toxic effects of mycotoxins in Europe. Toxicology Letters, Amsterdam, v. 127, n. 1/2, p. 19-28, 2002.

DIAZ, G. J.;ESPITIA, E. Occurrence of aflatoxin $\mathrm{M}_{1}$ in retail milk samples from Bogotá, Colombia. Food Additives and Contaminants, London, v. 23, n. 8, p. 811-815, 2006.

DRAGACCI, S.; FREMY, J. M. Application of immunoaffinity column cleanup to aflatoxin $M_{1}$ determination and survey in cheese. Journal of Food Protection, Des Moines, v. 59, n. 9, p. 1011-1013, 1996.

DRAGACCI, S.; GLEIZES, E.; FREMY, J. M.; CANDLISH, A. A. G. Use of immunoaffinity chromatography as a purification step for the determination of aflatoxin $M_{1}$ in cheeses. Food Additives and Contaminants, London, v. 12, n. 1, p. 59-65, 1995. 
DRAGACCI, S.; GROSSO, F.; GILBERT, J. Immunoaffinity column cleanup with liquid chromatography for determination of aflatoxin $\mathrm{M}_{1}$ in liquid milk: collaborative study. Journal of Association of Official Analytical Chemists International, Arlington, v. 84, n. 2, p. 437-443, 2001.

ELGERBI, A. M.; AIDOO, K. E.; CANDLISH, A. A. G.; TESTER, R. F. Occurrence of aflatoxin $M_{1}$ in randomly selected North African milk and cheese samples. Food Additives and Contaminants, London, v. 21, n. 6, p. $592-$ 597, 2004.

FAO. Worldwide regulations or mycotoxins in food and feed. Washington, DC: Food and Nutrition Report, 2003.

GALVANO, F.; GALOFARO, V.; GALVANO, G. Occurrence and stability of aflatoxin $\mathrm{M}_{1}$ in milk and milk products: a worldwide review. Journal of Food Protection, Des Moines, v. 59, n. 10, p. 1079-1090, 1996.

GALVANO, F.; GALOFARO, V.;RITIENI, A.;BOGNANNO, M.; ANGELIS, A. de; GALVANO, G. Survey of the occurrence of aflatoxin $M_{1}$ in dairy products marketed in Italy: second year of observation. Food Additives and Contaminants, London, v. 18, n. 7, p. 644-646, 2001.

GARRIDO, N. S.; IHA, M. H.; ORTOLANI, M. R. S.; FÁVARO, R. M. D. Occurrence of aflatoxins $M_{1}$ and $M_{2}$ in milk commercialized in Ribeirão Preto-SP, Brazil. Food Additives and Contaminants, London, v. 20, n. 1, p. 70$73,2003$.

GÜRBAY, A.;AYDIN, S.; GIRGIN, G.;ENGIN, A. B.;SAHIN, G. Assessment of aflatoxin $\mathrm{M}_{1}$ levels in milk in Ankara, Turkey. Food Control, Oxford, v. 17, p. 1-4, 2006.

HASSANIN, N. I. Stability of aflatoxin $M_{1}$ during manufacture and storage of yoghurt, yoghurt-cheese and acidified milk. Journal of the Science of Food and Agriculture, London, v. 65, p. 31-34, 1994.

INTERNATIONAL AGENCY FOR RESEARCH ON CANCER. Aflatoxins: some naturally occurring substances: food items and constituents, heterocyclic aromatic amines and mycotoxins. IARC Monographs on the Evaluation of Carcinogenic Risks to Humans, Lyon, v. 56, p. 245-395, 1993.

JECFA. Fifty-sixth meeting of the joint FAO/WHO expert committee on food additives: safety evaluation of certain mycotoxins in food. Geneva: WHO, 2001. (Food Additives Series, 47).

KAMBAR, A. A study on the occurrence of aflatoxin $\mathrm{M}_{1}$ in Iranian Feta Cheese. Food Control, Oxford, v. 17, p. 768775,2006

KAMBAR, U. Aflatoxin $\mathrm{M}_{1}$ contamination of some commercial Turkish cheeses from markets in Kars, Turkey. Fresenius Environmental Bulletin, [S.1.], v. 14, n. 11, p. 1046-1049, 2005.

KIM, E. K.; SHON, D. H.; RYU, D.; PARK, J. W.;HWANG, H. J.; KIM, Y. B. Occurrence of aflatoxin $M_{1}$ in Korean dairy products determined by ELISA and HPLC. Food Additives and Contaminants, London, v. 17, n. 1, p. 59-64, 2000.

LAFONT, P.; SIRIWARDANA, M.; LAFONT, J. Genotoxicity of hydroxy-aflatoxins $M_{1}$ and $M_{4}$. Microbiologie Aliments Nutrition, Zurique, v. 7, p. 1-8, 1989.

LÓPEZ, C.; RAMOS, L.; RAMADÁN, S.; BULACIO, L.; PEREZ, J. Distribution of aflatoxin $M_{1}$ in cheese obtained from milk artificially contaminated. International Journal of Food Microbiology, Amsterdam, v. 64, p. 211-215, 2001.

MARTINS, M. L.; MARTINS, H. M. Aflatoxin $M_{1}$ in yoghurts in Portugal. International Journal of Food Microbiology, Amsterdam, v. 91, p. 315-317, 2004.

NAKAJIMA, M.; TABATA, S.; AKIYAMA, H.; ITOH, Y.; TANAKA, T.; SUNAGAWA, H.; TYONAN, T.; YOSHIZAWA, T.; KUMAGAI, S. Occurrence of aflatoxin $\mathrm{M}_{1}$ in domestic milk in Japan during the winter season. Food Additives and Contaminants, London, v. 21, n. 5, p. 472-478, 2004.

OLIVEIRA, C. A. F.; GERMANO, P. M. L.; BIRD, C.; PINTO, C. A. Immunochemical assessment of aflatoxin $M_{1}$ in milk powder consumed by infants in São Paulo, Brazil. Food Additives and Contaminants, London, v. 14, n. 1, p. 7-10, 1997.

OLIVEIRA, C. A. F.; ROSMANINHO, J.; ROSIM, R. Aflatoxin $\mathrm{M}_{1}$ and cyclopiazonic acid in fluid milk traded in São Paulo, Brazil. Food Additives and Contaminants, London, v. 23, n. 2, p. 196-201, 2006. 
ORUC, H. H.; SONAL, S. Determination of aflatoxin $\mathrm{M}_{1}$ levels in cheese and milk consumed in Bursa, Turkey. Veterinary and Human Toxicology, Manhattan, v. 43, n. 5, p. 292-293, 2001.

ORUC, H. H.; CIBIK, R.; YILMAZ, E.; KALKANLI, O. Distribution and stability of aflatoxin $\mathrm{M}_{1}$ during processing and ripening of traditional white pickled cheese. Food Additives and Contaminants, London, v. 23, n. 2, p. 190195, 2006.

PARREIRAS, J. F. M.; GOMES, J. C. Ocorrência de aflatoxinas $M_{1}$ e $B_{1}$ em leite e forragens na microrregião de Viçosa/MG. Arquivos de Biologia e Tecnologia, Curitiba, v. 30, p. 253-265, 1987.

PEREIRA, M. M. G.; CARVALHO, E. P.;PRADO, G.;ROSA, C. A. R.; VELOSO, T.; SOUZA, L. A. F.; RIBEIRO, J. M. M. Aflatoxinas em alimentos destinados a bovinos e em amostras de leite da região de Lavras, Minas Gerais Brasil. Ciência e Agrotecnologia, Lavras, v. 29, n. 1, p. 106-112, 2005.

PIETRI, A.;BERTUZZI, T.;BERTUZZI, P.;PIVA, G. Aflatoxin $\mathrm{M}_{1}$ occurrence in samples of Grana Padano. Food Additives and Contaminants, London, v. 14, n. 4, p. 341-344, 1997.

PITTET, A. Natural occurrence of mycotoxins in foods and feeds-an updated review. Revue de Medecine Veterinaire, Toulouse, v. 149, n. 6, p. 479-492, 1998.

PRADO, G.; OLIVEIRA, M. S.; ABRANTES, F. M.; SANTOS, L. G.; SOARES, C. R.; VELOSO, T. Ocorrência de aflatoxina $M_{1}$ em leite consumido na cidade de Belo Horizonte - Minas Gerais, Brasil: agosto/98 à abril/99. Ciência e Tecnologia de Alimentos, Campinas, v. 19, n. 3, p. 420-423, 1999.

PRADO, G.;OLIVEIRA, M. S.;CARVALHO, E. P.;VELOSO, T.; SOUZA, L. A. F.; CARDOSO, A. C. F. Aflatoxina $\mathrm{M}_{1}$ em queijo prato e parmesão determinada por coluna de imunoafinidade e cromatografia líquida. Revista Instituto Adolfo Lutz, São Paulo, v. 60, n. 2, p. 147-151, 2001.

PRADO, G.; OLIVEIRA, M. S.; PEREIRA, M. L.; ABRANTES, F. M.; SANTOS, L. G.; VELOSO, T. Aflatoxin $\mathrm{M}_{1}$ in samples of "Minas" cheese commercialized in the city of Belo Horizonte - Minas Gerais, Brazil. Ciência e Tecnologia de Alimentos, Campinas, v. 20, n. 3, p. 398400, 2000.

ROUSSI, V.;GOVARIS, A.;VARAGOULI, A.;BOTSOGLOU, N. A. Occurrence of aflatoxin $M_{1}$ in raw and market milk commercialized in Greece. Food Additives and Contaminants, London, v. 19, n. 9, p. 863-868, 2002.

SABINO, M.; PURCHIO, A.; ZORZETTO, M. A. P. Variations in the levels of aflatoxin in cows milk consumed in the city of São Paulo, Brazil. Food Additives and Contaminants, London, v. 6, n. 3, p. 321-326, 1989.

SARIMEHMETOGLU, B.; KUPLULU, O.; CELIK, T. H. Detection of aflatoxin $M_{1}$ in cheese samples by ELISA. Food Control, Oxford, v. 15, p. 45-49, 2004.

SINNHUBER, R. O.; LEE, D. J.; WALES, J. H.; LANDERS, M. K.; KEYL, A. C. Hepatic carcinogenesis of aflatoxin $M_{1}$ in rainbow trout.Journal of the National Cancer Institute, Bethesda, v. 53, p. 1285-1288, 1974.

SOUZA, S. V. C.; VARGAS, E. A.; JUNQUEIRA, R. G. Eficiência de um kit de ELISA na detecção e quantificação de aflatoxina $M_{1}$ em leite e investigação da ocorrência no estado de Minas Gerais. Ciência e Tecnologia de Alimentos, Campinas, v. 19, n. 3, p. 401-405, 1999.

SRIVASTAVA, V. P.; BU-ABBAS, A.; ALAA-BASUNY; AL-JOHAR, W.; AL-MUFTI, S.; SIDDIQUI, M. K. J. Aflatoxin $\mathrm{M}_{1}$ contamination in commercial samples of milk and dairy products in Kuwait. Food Additives and Contaminants, London, v. 18, n. 11, p. 993-997, 2001.

SYLOS, C. M.; RODRIGUEZ-AMAYA, D. B.; CARVALHO, P. R. N. Occurrence of aflatoxin $M_{1}$ in milk and dairy products commercialized in Campinas, Brazil. Food Additives and Contaminants, London, v. 13, n. 2, p. 169-172, 1996.

TAVEIRA, J. A.; MIDIO, A. F. Incidence of aflatoxin $\mathrm{M}_{1}$ in milk marketed in São Paulo, Brazil. Italian Journal of Food Science, Pinerolo, v. 13, n. 4, p. 443-447, 2001.

TEKINSEN, K. K.; TEKINSEN, O. C. Aflatoxin $\mathrm{M}_{1}$ in white pickle and Van otlu (herb) cheeses consumed in southeastern Turkey. Food Control, Oxford, v. 16, p. 565568,2005 .

TUINSTRA, L. G. M.; ROOS, A. H.; TRUP, J. M. P. van. Liquid chromatographic determination of aflatoxin $M_{1}$ in milk powder using immunoaffinity columns for cleanup: interlaboratory study. Journal of Association of Official Analytical Chemists International, Arlington, v. 76, n. 6, p. 1248-1254, 1993.

YAROGLU, T.; ORUC, H. H.; TAYAR, M. Aflatoxin M levels in cheese samples from some provinces of Turkey. Food Control, Oxford, v. 16, p. 883-885, 2005. 